\title{
Scarlet Macaw, Ara macao, (Psittaciformes: Psittacidae) diet in Central Pacific Costa Rica
}

\author{
Christopher Vaughan ${ }^{1,2,3}$, Nicole Nemeth ${ }^{1,4} \&$ Leonel Marineros ${ }^{1}$ \\ International Institute for Wildlife Conservation and Management, Universidad Nacional, Heredia, Costa Rica. \\ Department of Wildlife Ecology, University of Wisconsin, Madison, WI 53706, USA. \\ Milwaukee Public Museum, Milwaukee, WI 53233, USA; cvaughan@wisc.edu \\ College of Veterinary Medicine and Biomedical Sciences, Colorado State University, Fort Collins, CO 80523, USA; \\ nnemeth@colostate.edu
}

Received 01-IV-2003. C Corrected 15-IV-2005. Accepted 29-III-2006.

\begin{abstract}
From 1993 to 1997, we observed Scarlet Macaw (Ara macao) feeding behavior in Central Pacific Costa Rica. Feeding data acquired in this study were not collected systematically, but opportunistically whenever macaws were observed feeding. To supplement feeding observations, we conducted interviews with local residents. Scarlet Macaws fed on seeds, fruits, leaves, flowers and/or bark of 43 plant species. Various plant parts eaten by macaws from several tree species contain secondary compounds toxic to humans, and additional species included in their diet are nonnative, introduced for agricultural purposes. Important macaw feeding tree species are Ceiba pentandra, Schizolobium parahybum, and Hura crepitans; these species are also crucial to this macaw population because of nest cavities they provide. The results of this study contribute to the conservation of Scarlet Macaws in Central Pacific Costa Rica through promoting protection of individual trees, and through local elementary school reforestation programs focusing on tree species that macaws use for feeding and/or nesting. Scarlet Macaw conservation is extremely important, as numerous population pressures have caused significant declines in macaw numbers in Costa Rica. Rev. Biol. Trop. 54 (3): 919-926. Epub 2006 Sept. 29.
\end{abstract}

Key words: conservation, Costa Rica, diet, feeding, Scarlet Macaws, Ara macao.

Scarlet Macaws Ara macao are classified as threatened (Appendix I) under the Convention on International Trade in Endangered Species (CITES). Scarlet Macaw numbers have declined throughout its range because of habitat loss, direct hunting, and capture for the pet trade (Forshaw 1989, Vaughan et al. 1991, Wiedenfeld 1994, IñigoElías 1996). In Costa Rica, Scarlet Macaws once resided on both the Pacific and Caribbean slopes between sea level and approximately $1500 \mathrm{~m}$ elevation (Vaughan 1983). Small groups of macaws ( $<25$ individuals) have been observed in the Estrella Valley, Tempisque Conservation Area and in Northeastern Costa
Rica. However, approximately 700 individuals live in the Osa Conservation Area and approximately 400 individuals in the Central Pacific Conservation Area (ACOPAC) (Stiles and Skutch 1989, Vaughan et al. 1991, Vaughan et al. 2005). We studied the diet and feeding habits of the latter population. While macaw species are known to feed on fruits, seeds, nuts, and vegetable matter (Forshaw 1989), information on the food habits of Scarlet Macaws are scarce (Munn 1988, Marineros and Vaughan 1995, Nycander et al. 1995, Gilardi 1996, Iñigo-Elías 1996). The objective of this study was to document Scarlet Macaw diet in Central Pacific Costa Rica. 


\section{MATERIALS AND METHODS}

Scarlet Macaw home range in the Central Pacific Conservation Areas was estimated in 1995 at approximately $560 \mathrm{~km}^{2}\left(84^{\circ} 37^{\prime} \mathrm{W}\right.$, $9^{\circ} 47^{\prime} \mathrm{N}$ ) and includes four life zones: tropical dry forest with transition to humid, tropical humid forest, premontane and montane forest, and tropical wet forest (Tosi 1969, Marineros and Vaughan 1995). Approximately $90 \%$ of the study area contained altered habitats, which included cattle pasture, fruit orchards, timber harvesting areas, rice fields and abandoned farmland/pasture; forest remnants $>40$-ha were scarce among all habitats in this study. Range annual temperatures were between $25-30{ }^{\circ} \mathrm{C}$ (Coen 1983). There is a moderate dry season from November to April, and a severe wet to torrential wet season from May to December, in which $90 \%$ of annual precipitation falls (2 $487 \mathrm{~mm}$ in lowlands to $3299 \mathrm{~mm}$ in higher elevations) (Cifuentes et al. 1983).

From 1993 to 1997, we made Scarlet Macaw feeding observations with 7 x 35 binoculars from roads and forest trails. Feeding data acquired in this study were not collected systematically, but opportunistically whenever macaws were observed feeding. To supplement feeding observations, we conducted interviews with local residents concerning Scarlet Macaw feeding habits. During both observations and interviews, we recorded the tree species fed upon by macaws, plant parts eaten, and date observed. Unidentified fruits dropped by macaws while feeding were recovered for identification by botanists (see acknowledgments). We pooled fruits and seeds into one category under plant parts eaten, since it was difficult to distinguish them from each other when macaws were feeding (Table 2).

\section{RESULTS}

Observations occurred during peak Scarlet Macaw feeding hours, which took place immediately after early morning movements from Guacalillo Mangrove Reserve (0630-0800 h), and just prior to return flights to roosting sites (1500-1700 h) (Marineros and Vaughan 1995). Birds were most often seen feeding atop the forest canopy, in trees along forest edge, and in isolated trees or tree clusters within cattle ranches.

From a total of 160 feeding observations, Scarlet Macaws fed on 43 different plant species (41 trees, one bromeliad, and one orchid) (Table 1). Fruits and seeds accounted for the majority of observations ( $85.4 \%$ ), while young leaves, flowers, bark, and unknown plant parts were much less frequently observed. Fruits and/or seeds were eaten from 25 tree species, leaves from seven species, bark from three species, flowers from three species, and unknown plant parts from nine species. Fourteen of 20 plant species $(70 \%$ ) cited by locals for macaw feeding were confirmed by our observations. Six unconfirmed plant species reported by locals were Brosimum utile, Guarea glabra, Hymenaea courbaril, Pseudolmedia sp., Sterculia apetala, and Vitex cooperi (Vaughan et al. 1991, Marineros and Vaughan 1995) (Table 1).

Various tree species used by macaws for food in this study were unique in that they contained secondary compounds toxic to human plant parts, were nonnative to Costa Rica, or served the dual purpose of feeding and nesting trees. Tree species fed upon by macaws in this study that contain secondary compounds toxic to humans within their bark, seeds or fruit included: Hura crepitans, Cedrela odorata, Bursera simaruba, and Anacardium occidentalis. Beach almond (Terminalia catappa), Teak (Tectona grandis), and Gmelina arborea are introduced tree species that form part of Scarlet Macaws' diet in Central Pacific Costa Rica. Finally, Ceiba pentandra, Schizolobium parahybum, $H$. crepitans, and Terminalia oblonga provide food for macaws, as well as nesting cavities (Vaughan et al. 2003b). Tree species included in our study were most often located within open areas partially cleared for agriculture or other human activities due to a higher frequency of observations in these areas (Table 1). 
TABLE 1

Plant species, number of feeding bouts, percent of diet, months eaten, and habitats where eaten for Scarlet Macaws (A. macao) in Central Pacific Costa Rica (1993-1997)

No. feeding
bouts $\%$ diet Month and plant part eaten $\begin{gathered}\text { Position, } \\ \text { Abundance, } \\ \text { Habitat(s) }\end{gathered}$

\section{ACANTHACEAE}

Bravaisia integerrima (Spreng.) Stand.

\section{ANACARDIACEAE}

Anacardium excelsum (Bert. \& Balb.) Skeel

Anacardium occidentalis L.

Spondias mombin L.

Spondias purpurea $\mathrm{L}$.

\section{APOCYNACEAE}

Aspidosperma spuceanum

Stemmadenia donnell-smithii (Rose) Woodson

\section{BIGNONIACEAE}

Tabebuia rosea (Vertol.) DC.

\section{BOMBACACEAE}

Bernoullia flammea Oliv. (*)

Ceiba pentandra (L.) Gaertn.

Ochroma pyramidale Swartz

Quararibaea asterolpsis Pittier

\section{BORAGINAGEAE}

Cordia collococca $\mathrm{L}$.

BROMELIACAE

Bromelia sp.

\section{BURSERACEAE}

Bursera simaruba (L.) Sarg.

\section{CAESALPINIACEAE}

Hymenaea courbaril L.

Schizolobium parahybum (Vell.) Blake

\section{CHRYSOBALANACEAE}

Licania platypus (Hemsl.) Fritsch

\section{COMBRETACEAE}

Terminalia catappa $(*)$

16,3

1

10
1

3

0.6

Apr (?)

C, o, A

9,1

2

2,1

2

1

1

2

1

3,1

2

1

5

1

0.6

$$
\text { Jan-May (fr/s), Apr (b) }
$$

C, f, RAO

1.3

$$
\text { Mar-Apr (fr/s) }
$$

1.9 Nov-Dec (fr/s), Feb-Mar (1)

C, f, PLO

1.3

Sept-Oct (fr/s)

U, o, POLAP

\section{6}

0.6

Apr (1)

C, f, PL

$$
?
$$

U, o, A

Jan, Mar (fr/s)

C, f, APLO

$$
0.6
$$

$\operatorname{Mar}(\mathrm{fr} / \mathrm{s})$

C, f, O

2.5

Feb-May (fr/s, b)

C, o, APO

Dec-Jan (fl)

C, o, AGP

0.6

Jun (fr/s)

C, f, WA

3.1

Jun-Aug (fr/s)

1.9

Apr-May (1)

$$
\text { Apr (fr/s) }
$$

C, f, PLO

S, r, PL; S, c, OG

\section{$?$}

C, f, PL

11.9

Jan-Jun, Aug, Nov (fr/s),

Feb-Mar (1)

C, o, GO

0.6

July (1)

C, f, AL

Jun-Aug (fr/s)
C, f, O 
TABLE 1 (Continued)

Plant species, number of feeding bouts, percent of diet, months eaten, and habitats where eaten for Scarlet Macaws (A. macao) in Central Pacific Costa Rica (1993-1997)

No. feeding
bouts $\quad \%$ diet $\quad$ Month and plant part eaten

Terminalia oblonga (R. \& P.) Steud.

\section{EUPHORBIACEAE}

Hura crepitans L.

Sapium jamaicense Swartz

FABACEAE

Erythrina sp.
Lonchocarpus acuminatus (Schlecht.) Sousa

MELIACEAE

Cedrela odorata L.

Guarea glabra Vahl.

\section{MIMOSACEAE}

Enterolobium cyclocarpum (Jacq.) Griseb.

Inga vera

Pithecellobium saman (Jacq.) Benth

\section{MORACEAE}

Brosimum alicastrum Swartz

Brosimum utile (HBK.) Pittier

Clarisia biflora R. \& P.

Ficus insipida Willd

Ficus sp.

Pseudolmedia oyyphyllaria Donn. Smith.

\section{MYRISTICACEAE}

Virola sebifera Warb.

\section{ORCHIDACEAE}

Epidendron sp.

PALMAE

Scheelea rostrata (Oerst.) Burret

\section{SAPOTACEAE}

Pouteria sp.
$1,1,1$
1.9
Feb (fr/s,fl, b)
C, o, RA

Position, Abundance, Habitat(s)

$\begin{array}{cccc}18,1 & 11.9 & \begin{array}{c}\text { Jan-May, Jun, Aug (fr/s), } \\ \text { Nov (1) }\end{array} & \text { C, r, AL } \\ 1 & 0.6 & \text { Jul (?) } & \text { C, o, AL }\end{array}$

$2 \quad 1.3$

1.3
0.6

$$
\text { Jan-Feb (fl) }
$$

C, r, O

1

July (?)

$\mathrm{U}, \mathrm{r}$

1

0.6

Nov (fr/s)

C, o, PL

$$
?
$$

$\mathrm{U}, \mathrm{r}$

$\begin{array}{cccc}3,2 & 3.1 & \text { Feb-Apr (fr/s), Mar (l) } & \text { C, o, PLO } \\ 2 & 1.3 & \text { Jan (fr/s), May (?) } & \text { U, f, R } \\ 1 & 0.6 & \text { Dec (fr/s) } & \text { C, f, OAP }\end{array}$

$\begin{array}{ll}5 & 3.1 \\ 1 & 0.6 \\ 1 & 0.6 \\ 4 & 2.5 \\ 1 & 0.6\end{array}$
Mar, Jun-Aug (fr/s)
$\operatorname{Mar}(\mathrm{fr} / \mathrm{s})$
Jan (?)

C, f, AL

$\mathrm{C}, \mathrm{f}, \mathrm{Ll}$

C, v, APL

Jun-Aug (fr/s)

$\mathrm{S}, \mathrm{v}, \mathrm{R}$

Feb (fr/s)

$$
\text { ? }
$$

Jul (fr/s)

C, o, PL

1

0.6

0.6

Nov (?)

38

23.9

Jan, Apr-Aug (fr/s)

S, f, WO

1

0.6
$\mathrm{U}, \mathrm{o}, \mathrm{A}$ 
TABLE 1 (Continued)

Plant species, number of feeding bouts, percent of diet, months eaten, and habitats where eaten for Scarlet Macaws (A. macao) in Central Pacific Costa Rica (1993-1997)

No. feeding
bouts $\%$ diet Month and plant part eaten $\begin{gathered}\text { Position, } \\ \text { Abundance, } \\ \text { Habitat(s) }\end{gathered}$

\section{STERCULIACEAE}

Sterculia apetala (Jacq.) Karst

VERBENACEAE

Gmelina arborea $(*)$

Tectona grandis L. (*)

Vitex cooperi Standl.

Total observations
C, o, PL

2

1.3

0.6
June-July (fr/s)
Feb (fr/s)

C, c, OP

C, c, OP

?

160

*non-native to Costa Rica. Plant parts eaten key: fr-fruit, s-seeds, l-new leaves, b-bark, fl-flowers, fr/s-fruit or seed; Habitat
key: R-riparian (streamside), A-alluvial (floodable with good drainage), W-swamp (floodable with poor drainage), P-plateau
or flatlands (slopes $<5 \%$ with moderate drainage), L-slope (slopes $>5 \%$ with good drainage), I-ridge (well drained to exces-
sive drainage), O-open country (cultivated areas and pasture), G-secondary forest and P-plantations; Physiognomic positions
key: C-canopy, S-subcanopy, U-understory and T-treelet $(<10 \mathrm{~cm}$ dbh or $5 \mathrm{~m}$ tall); Abundance key: c-common $(>10 /$ ha),
f-frequent $(1-10 /$ ha), o-occasional $(0.1-1 /$ ha), r-rare $(0.01-0.1 / \mathrm{ha})$ and v-very rare $(<0.01 /$ ha) (Hartshorn and Poveda 1983$)$.

\section{DISCUSSION}

General diet information: According to previous studies, Scarlet Macaws feed on a diverse variety of plant species and plant parts among available habitats (Munn 1992, Marineros and Vaughan 1995, Nycander et al. 1995, Gilardi 1996). In our study, fruits and seeds of Brosimum alicastrum, Scheelea rostrata, and $H$. crepitans were common food sources for macaws, and were utilized during both wet and dry seasons (Table 1). Fruits of C. pentandra and Anacardium excelsum were heavily consumed during the dry season when macaws rear their offspring; we found $A$. excelsum fruit parts in chick crops in March. Cultivated tree species fed upon by macaws in our study included A. occidentalis and Spondias purpurea.

Our results may represent certain biases, and are somewhat inconsistent with other macaw diet studies. Macaw feeding behavior was easiest to observe in scattered trees among pasture or forest edges. Therefore, our study may represent a bias toward plant species that are common in edge or open habitat, other important plant species found exclusively within forests may be under-represented. Socratea, Calycophyllum, and Apeiba are plant genera native to Costa Rica and the study area, and while eaten by macaws in Manu, Peru (Nycander et al. 1995), are still unconfirmed food sources for Scarlet Macaws in Central Pacific Costa Rica

Plant parts eaten: Scarlet Macaws fed mostly on fruits and seeds in our study, consistent with previous findings (Janzen 1983) (Table 2). Fruits and/or seeds of $A$. excelsum, $C$. pentandra, and $H$. crepitans were eaten relatively often during the dry season. B. alicastrum and $S$. rostrata were common species fed upon during the wet season, when generally fewer tree species produce flowers or fruits (Coen 1983, McCoy et al. 1990). As with many deciduous tree species, $S$. parahybum dropped its leaves and produces fruits in the dry season; Scarlet Macaws fed on its fruits and/or seeds during the dry season and on its young, tender leaves during the wet season (Table 1).

Plants with secondary compounds toxic to humans: The sap of $H$. crepitans has secondary compounds toxic to humans (Hartshorn 
TABLE 2

Plant parts eaten by Scarlet Macaws (A. macao) in Central Pacific Costa Rica (1993-97, $n=155$ )

$\begin{array}{lc}\quad \text { Plant part } & \text { Quantity } \\ \text { Fruits/seeds* } & 133(85.8 \%) \\ \text { Flowers } & 4(2.6 \%) \\ \text { Leaves } & 12(7.7 \%) \\ \text { Bark } & 3(1.9 \%) \\ \text { Unidentified } & 3(1.9 \%) \\ \text { Total } & 155\end{array}$

*Fruits and seeds are combined into one category.

1983), and in our study area, whole fruits fell from trees and eventually decayed on the ground, untouched by most wildlife. However, we observed Scarlet Macaws eating fruits, seeds, and bark of $H$. crepitans throughout most of the year in Central Pacific Costa Rica, consistent with previous observations (Janzen 1983). Scarlet Macaws also feed upon this species in Belize (Kainer 1991), Peru (Munn 1992), and Columbia (Forshaw 1989). According to Janzen (1983), C. odorata and $B$. simaruba seeds and fruits were not eaten by some psittacine species because of their secondary compounds toxic to humans. However, Scarlet Macaws in ACOPAC ate plant parts from both tree species, as well as from $\mathrm{A}$. occidentalis, which is also known to contain toxins (Hartshorn and Gentry 1983) (Table 1).

Introduced tree species: A variety of nonnative tree species have been documented as providing quality nesting cavity and food sources to various psittacine species (Braby and Rantzau 1988, Beissinger and Bucher 1992, Wood 1992, Galetti 1993, Woodall 1993). Scarlet Macaws in our study have been observed feeding on Beach Almond ( $T$. catappa), Teak (T. grandis) and G. arborea, all exotic species to Costa Rica. The latter two have been extensively planted as forestry trees in lowland Costa Rica (C.S.V., pers. obs.).
Scarlet Macaws feed heavily on T. catappa on the Osa Peninsula, Costa Rica (Janzen 1983). T. catappa is a relatively low growing tree species, and is common along beaches and in city parks in lowland coastal areas. Therefore, macaws are highly visible while feeding on this species. Cultivated plant species could potentially help sustain Scarlet Macaws in ACOPAC as habitat destruction continues to remove native food sources, as apparently occurred with endangered Orange-bellied Parrots (Neophema chrysogaster) feeding on cultivated sunflowers (Helianthus annus) in Australia (Eckert 1990).

Nesting and feeding tree species: Scarlet Macaws used many nesting tree species as food sources in our study (Marineros and Vaughan 1995, Vaughan et al. 1999, Bonadie and Bacon 2000). Ceiba pentandra, S. parahybum, $H$. crepitans and $T$. oblonga are tree species that provide both food and nesting cavities for macaws in ACOPAC (Vaughan et al. 2003b). These species are crucial to Scarlet Macaw conservation in ACOPAC because of their abundance in the region, their use as nest sites, and because they are food sources during both wet and dry seasons.

Ecotourism: Nature guides lead tourists to specific nesting and fruiting trees in and around Carara National Park to observe macaws and other wildlife species feeding. Scarlet Macaw activity in itself attracts tourists to the region, potentially increasing economic gains for local people (Marineros and Vaughan 1995). However, additional work is needed to develop tourism on a local level, as currently most tourism dollars funnel into large tourist companies (Vaughan 1999).

Management related to diet: Knowledge of diet has facilitated widespread conservation efforts in the study region. We have provided local landowners with lists of tree species used by macaws for feeding and nesting in hopes that they will protect existing trees, as well as plant additional trees. This list includes exotic tree species: T. catappa, T. grandis and $G$. 
arborea. However, these exotic species should be cultivated with caution within controlled areas, in which they do not infringe upon native forest plant species. Planting Terminalia catappa along coastlines and in towns has encouraged feeding by macaws. Finally, forestry nurseries that specialize on key macaw nesting and feeding tree species have been initiated in the towns of Quebrada Ganado, Tarcoles and Bijagual, each of which lies within or borders the study area. Adult community members help guide local elementary school children in these efforts. These nurseries, as well as macaw presence within meters of homes, encourages a positive attitude towards macaws and conservation (Vaughan et al. 2003a).

Future studies: Further studies on Scarlet Macaw diet are needed. These might include: a) a systematic diet study conducted over a 12-month period, b) detailing local temporal and spatial macaw movements to food sources through radio telemetry, c) studying effects of the availability of exotic species on macaw feeding habits, and d) examining the mechanism that allows macaws to consume plants with secondary compounds toxic to humans.

\section{ACKNOWLEDGMENTS}

We are grateful to M. Fisher for assistance in data collection and to Quirico Jimenez and Nelson Zamora, from INBio, for plant identification. We also thank the administrators at Carara National Park for housing us during the study and Mark Myers, who helped improve earlier versions of the manuscript. The Organization of American States, The Parrot Society-UK, Idea Wild, Wildlife Trust and Universidad Nacional of Costa Rica provided financial support and we are appreciative to them.

\section{RESUMEN}

Entre 1993-97, observamos el comportamiento de alimentación de la lapa roja (Ara macao) en el Pacifico Central de Costa Rica. La lapa roja se alimentó de semillas, frutas, hojas, flores y corteza de 43 especies de plantas. Varias partes de las plantas comidas por las lapas contienen compuestos secundarios tóxicos al ser humano, y especies adicionales incluidas en la dieta son exóticas; introducidas por razones agrícolas, forestales o estéticas. Especies de árboles importantes como alimento de la lapa roja incluyen: Ceiba pentandra, Schizolobium parahybum, y Hura crepitans; también son criticas para la población de la lapa roja debido a proveen cavidades para anidación. Los resultados de este estudio contribuyen a la conservación de la lapa roja en el Pacifico Central de Costa Rica a través de la promoción de la protección de árboles individuales y programas de reforestación a nivel de escuela primaria que se enfocan en especies de árboles que la lapa utiliza para alimentación o anidación. La conservación de la lapa roja es importante, debido al declive de sus números en Costa Rica.

Palabras clave: alimentación, Ara macao, conservación, Costa Rica, dieta, lapa roja.

\section{REFERENCES}

Beissinger, S. \& E. Bucher. 1992. Sustainable harvesting of parrots for conservation, p. 73-115. In S. Beissinger \& N. Snyder (eds.). New World Parrots in Crisis: Solutions from Conservation Biology. Smithsonian Institution, Washington, D.C., EEUU.

Bonadie, W.A. \& P.R. Bacon. 2000. Year-round utilization of fragmented palm swamp forest by Red-bellied macaws (Ara manilata) and Orange-winged parrots (Amazona amazonica) in the Nariva Swamp (Trinidad). Biol. Conserv. 95: 1-5.

Braby, M. \& C. Rantzau. 1988. Observations on feeding flocks of the red-rumped parrot Psephotus haematonotus in Parklands near Melbourne, Victoria. Aust. Bird Watcher 12: 150-153.

Cifuentes, M., W. Alpizar \& F. Barroso. 1983. Plan de manejo y desarrollo: Reserva Biológica Carara. Servicio de Parques Nacionales, Ministerio de Recursos Naturales, San José, Costa Rica. 72 p.

Coen, E. 1983. Climate, p. 35-46. In D. Janzen (ed.). Costa Rican Natural History. University of Chicago, Chicago, Illinois, USA.

Eckert, J. 1990. Orange-bellied parrots feeding on a cultivated crop. S. Aust. Ornithol. 31: 16-17.

Forshaw, J. 1989. Parrots of the World. Landsdowne, Melbourne, Australia. 584 p.

Galetti, M. 1993. Diet of the scaly-headed parrot (Pionus maximiliani) in a semideciduous forest in southeastern Brazil. Biotropica 25: 419-425. 
Gilardi, J. 1996. Ecology of parrots in the Peruvian Amazon: Habitat use, nutrition, and geography. Ph.D. Thesis, University of California, Davis, California, USA. 103 p.

Hartshorn, G. 1983. Hura crepitans (jabillo, sandbox tree), p. 251-252. In D. Janzen (ed.). Costa Rican Natural History. University of Chicago, Chicago, Illinois, USA.

Hartshorn, G. \& A. Gentry. 1983. Anacardium excelsum (Espavel, Espave, Acajou), p. 189-190. In D. Janzen (ed.). Costa Rican Natural History. University of Chicago, Chicago, Illinois, USA.

Hartshorn, G. \& L. Poveda. 1983. Checklist of trees, p. 158-183. In D. Janzen (ed.). Costa Rican Natural History. University of Chicago, Chicago, Illinois.

Iñigo-Elías, E. 1996. Ecology and breeding biology of the Scarlet macaw (Ara macao) in the Usumacinta drainage basin of Mexico and Guatemala, Ph.D. Thesis, University of Florida, Gainesville, Florida, USA. $117 \mathrm{p}$

Janzen, D. 1983. Costa Rican Natural History. University of Chicago, Chicago, Illinois, USA. 823 p.

Kainer, M. 1991. Conservation of the Scarlet Macaw (Ara macao) in a subtropical moist forest life zone, Belize, Central America, p. 5-10. In J. Clinton-Eitniear (ed.). The Proceedings of the First Mesoamerican Workshop on the Conservation and Management of Macaws, Center for the Study of Tropical Birds, San Antonio, Texas, USA.

Marineros, L. \& C. Vaughan. 1995. Scarlet macaws of Carara, p. 445-467. In J. Abramson, B. Speer \& J. Thomsen (eds.). The large macaws: their care, breeding and conservation. Raintree, Fort Bragg, California, USA.

McCoy, M., C. Vaughan, M. Rodriguez \& D. Kitchen. 1990. Seasonal movement, home range, activity and diet of collared peccaries (Tayassu tajacu) in Costa Rican dry forest. Vida Silv. Neotrop. 2: 6-20.

Munn, C. 1988. The real macaws. Animal Kingdom 91: 20-26.

Munn, C. 1992. Macaw biology and ecotourism or "when a bird in the hand is worth two in the bush", p. $47-$ 72. In S. Beissinger \& N. Snyder (eds.). New World Parrots in crisis: solutions from conservation biology. Smithsonian Institution, Washington, D.C., USA.
Nycander, E., D. Blanco, K. Holle, A. Del Campo, C. Munn, J. Moscoso \& D. Ricalde. 1995. Manu and Tamopata: Nesting success and techniques for increasing reproduction in wild macaws in Southeastern Peru, p. 423-443. In J. Abramson, B. Speer \& J. Thomsen (eds.). The large macaws: their care, breeding and conservation. Raintree, Fort Bragg, California, USA.

Stiles, G. \& A. Skutch. 1989. Birds of Costa Rica. Cornell University, Ithaca, New York, USA. 511 p.

Tosi, J. \& L. Holdridge. 1966. Ecological map of Costa Rica. Tropical Science Center, San José, Costa Rica.

Vaughan, C. 1983. Potential habitat for endangered species in Costa Rica. Universidad Nacional, Heredia, Costa Rica, 49 p.

Vaughan, C. 1999. Do local communities in developing countries benefit from ecotourism in national parks and protected areas? Vida Silv. Neotrop. 8: 3-9.

Vaughan, C., M. McCoy \& J. Liske. 1991. Ecology and management of the Scarlet Macaw in Carara Biological Reserve, p. 23-34. In J. Clinton-Eitniear (ed.). Proceedings of the First Mesoamerican Workshop on the Conservation and Management of Macaws, Center for the Study of Tropical Birds, San Antonio, Texas, USA.

Vaughan, C., J. Gack, H. Solorzano \& R. Ray. 2003a. The effect of environmental education on school children, their parents and community members: A study of intergenerational and intercommunity learning. J. Environm. Ed. 34: 12-21.

Vaughan, C., N. Nemeth, J. Cary \& S. Temple. 2005. Response of a Scarlet Macaw (Ara macao) population to conservation measures. Birdlife Int. 15:119-130.

Vaughan, C., N. Nemeth \& L. Marineros 2003b. Ecology and management of natural and artificial scarlet macaw (Ara macao) nest cavities in Costa Rica. Ornitol. Neotrop. 14: 381-396.

Wiedenfeld, D. 1994. A new subspecies of scarlet macaw (Ara macao) and its status and conservation. Ornitol. Neotrop. 5: 99-104.

Wood, K. 1992. Cockatoos, parrots and lorikeets eating food from introduced trees and shrubs in the Illawarra region. Aust. Birds 25: 79-81.

Woodall, P. 1993. Australian king-parrot feeding on the climbing vine Pothos longpipes. Sunbird 23: 107-108. 